\title{
The People's Republic of China and the Development of Contemporary International Law: Review and Prospects*
}

\author{
Zewei Yang**
}

The development of Chinese international jurisprudence over the past 70 years can be divided into three stages: fledging; recovery and development; and flourishing. During the period, Chinese international lawyers have made great contributions to the development of international law through, inter alia, the Five Principles of Peaceful Co-existence, recognition and succession, the peaceful settlement of international disputes, the Belt and Road Initiative, the Shared Future for Mankind, and so forth. However, participation in international legislation and international judicial activities needs to be further improved, because the theoretical ground for China's foreign policy and diplomatic practice is still insufficient and academic works with global influence are not enough yet. The development of Chinese international law follows such trends: more valuable interpretation and application of international law; the theoretical innovation of international law; and the improvement of China's discourse power. These are important missions for Chinese international lawyers.

\section{Keywords}

Chinese International Law, International Jurisprudence, Belt and Road Initiative, A Community of Shared Future for Mankind

* This paper is a part of the research results of a major project of the national key research base for humanities and social sciences under the Ministry of Education of China (No. 17JJD820006) chaired by Prof. Yang Zewei, titled, "A Study on International Legal Issues Relating to the Protection of China's Rights and Interests."

All the websites cited in this article were last visited on October 18, 2020.

** Distinguished Professor of Chang Jiang Scholars Program of Ministry of Education; Luojia Distinguished Professor of International Law Institute, China Institute of Boundary and Ocean Studies, and Collaborative Innovation Center for Territorial Sovereignty and Maritime Rights at Wuhan University. A.B. (Hunan Normal Univ.), M.A./Ph.D.(Wuhan). ORCID: http://orcid.org/0000-0001-9937-2741. The author may be contacted at: fxyyzw@whu.edu.cn/Address: Luojia Hill, Wuhan, Hubei Province, 430072, P.R. China. 


\section{Introduction}

The establishment of the People's Republic of China (PRC) in 1949 was a historic event. It was significant to the postwar power politics in East Asia. New China initiated revolutionary ideas for the renovation of old China. Accordingly, China should change its views of foreign policy and international law. PRC finally joined the international society as a completely independent State. The Common Program of the Chinese People's Political Consultative Conference in 1949 expressly provided: "The principle of the foreign policy of the People's Republic of China is protection of the independence, freedom, integrity of territory and sovereignty of the country, upholding of lasting international peace and friendly co-operation between the peoples of all countries, and opposition to the imperialist policy of aggression and war." ${ }^{\prime}$ For the past seven decades, while extensively applying the rules and regulations, PRC has introduced many innovations to contemporary international law. It is theoretically and practically significance to review the development of international law in China 1949 to find a right way for the next stage of international law studies in the time of G2.

This article is divided into six parts including Introduction and Conclusion. Part two will elaborate the progress of Chinese international law over the past 70 years. Part three will analyze the major contributions of China to contemporary international law. Part four will systematically summarize the major characteristics and problems in Chinese international law over the last 70 years. Part five will indicate the future orientation of Chinese international law.

\section{Development of Chinese International Law since 1949: Three Periods}

\section{A. Preliminarily Period (1949-78)}

1. The First Phase (from 1949 to the late 1950s).

Shortly after its establishment, PRC should solve many international legal issue, such as recognition and succession, abolishment, alteration and establishment of

The Common Program of Chinese People's Political Consultative Conference, Sept. 29, 1949, art. 54, https://source books.fordham.edu/mod/1949-ccp-program.asp. 
treaties, nationality issues, its rights and interests in international organizations, etc. In the course of handling and addressing these issues, the Chinese government urgently needed the knowledge of modern international law. ${ }^{2}$

From 1949 to 1952, some institutions of higher education introduced international law courses, including Peking University, Wuhan University, Renmin University of China, and Sun Yat-sen University, among which Renmin University of China had employed an expert from the Soviet Union to teach international law. In 1952, Chinese institutions of higher education were subject to adjustments. As a result, international law education was suspended. Since 1956, Peking University, Peking College of Political Science and Law, and other institutions of higher education resumed or newly started to teach undergraduates international law. Meanwhile, each school and department of politics and law had systematically compiled teaching and reference materials. ${ }^{3}$

During this period, abundant Soviet works on international law were translated and published in the field of Chinese international law, including the SOVIET UNION and International LaW, ${ }^{4}$ United Nations: A History ${ }^{5}$ and Problem of Territorial WAters in InTERnAtional LAW. ${ }^{6}$ Moreover, there were dozens of academic papers such as International Law and International Organization by Vyshinsky, Some of the Main Questions of the Modern Theory of International Law by Korovin, Discussions and Conclusions on Theoretical Issues in International Law published by the Editorial Department of the STATE AND LAW (a journal from the Soviet Union), and so forth. Chinese scholars simultaneously translated and published some authoritative European and American works on international law, such as OppenHeim's International Law, ${ }^{7}$ A Guide to Diplomatic Practice, ${ }^{8}$ The International Law of the Sea, ${ }^{9}$ and The United Nations Specialized Agencies. ${ }^{10}$

It is noteworthy that the Chinese government released the Declaration on

2 C. Xiaoxia \& Z. Wenbin, Review and Prospect of Chinese International Law [国国际法学的回顾与展望], 5 LEGAL STUD. \& RES. [法律学习与研究] 7 (1996).

3 S. Jin, International Public Law [国际公法学], in ForTy YeARS OF ChINESE LAW [中国法学四十年] 540 (Z. Youyu eds., 1989).

4 Kozevnikov, Soviet Union and International Law [苏维埃国家与国际法] (Renmin University of China Press, 1955).

5 Sergej Krylov, United Nations: A History (vol. 1) [联合国史料(第1卷)] (Renmin University of China Press, 1955).

6 Nikolayev, Problem of Territorial Waters in International Law [国际法中的领水问题] (Law Press, 1955).

7 H. Lauterpacht (ed.), Oppenheim’s International Law [奥本海国际法] (trans. by Law Press, 1955).

8 E. Satow, A Guide to Diplomatic Practice [外交实践指南] (trans. by World Affairs Press, 1955).

9 A. Higgins \& C. Colombos, The International Law of the Sea [海上国际法] (trans. by Law Press, 1957).

10 R. Menaeli, The United Nations Specialized Agencies [联合国专门机构] (trans. by World Affairs Press [世界知识出 版社], 1957). 
Territorial Sea in $1958 .{ }^{11}$ Thereafter, some scholars published research papers ${ }^{12}$ which was compiled into On the Territorial SeA Issue of China. ${ }^{13}$ Since the 1950s, the PRC Ministry of Foreign Affairs has published some collections of treaties and foreign documents including A Collection of the Treaties of the People's Republic of China, ${ }^{14}$ A Collection of International Treaties and A Collection of Documents on the Foreign Relations, ${ }^{15}$ and A Collection of Documents on AgreEment between the Government of The People's Republic of China and the Government of the Union of Myanmar on China-Myanmar Border Areas. ${ }^{16}$

At this stage, Soviet international law had a significant influence on the education and research of international law of China. In particular, the teaching materials, textbooks and expertise were mainly adopted from those of the Soviet Union. ${ }^{17}$

\section{The Second Phase (Early 1960s-1978).}

"Left-leaning" ideas and legal nihilism prevailed at this time mainly due to the Cultural Revolution, severely impeding and withering the progress of Chinese international law for almost two decades.

Regarding the education of international law at that time, some colleges and universities of politics and law were shut down and international law teachings in other universities and colleges were limited. As for research on international law, scholars in this field were either forced to halt their academic research or sent to villages to engage in physical work. For instance, Professor Wang Tieya from Peking University was sent to a farm in Poyang Lake. ${ }^{18}$ Then, even a single paper on international law was not found in newspapers or magazines from 1961 to 1978. Luckily, research on international law was not completely suspended. Some experts

11 [中华人民共和国政府关于领海的声明] (1958年9月4日) See also Exit and Entry Administration Law [出境入境 管理法] (promulgated by the Standing Comm. Nat'l People's Cong., June 30, 2012, effective July 1, 2013), art. 41, 2012 Fagui Huibian 283, 291.

12 Z. Gengsheng, The Significance of China Government's Statement on Territorial Waters [我政府关于领海的声明的重 大意义], 18 WORLD AFF. [世界知识] (1958).

13 F. Tao, On the Territorial Sea Issue of China [关于我国的领海问题] (World Affairs Press, 1959).

14 A Collection of the Treaties of the People’s Republic of China (1949-1960) [中华人民共和国条约集] (PRC Ministry of Foreign Affairs eds., 1960).

15 a Collection of International Treaties and A Collection of Documents on the Foreign Relations of the People's RePuBlic OF ChINA (1949-1963) [中华人民共和国对外关系文件集] (World Affairs Press, 1965).

16 A Collection of Documents on Agreement between the Government of The People's Republic of China and the Government of the Union of Myanmar on China-Myanmar Border Areas [中华人民共和国和缅甸联邦边界条约文 件集l (Law Press, 1960).

17 C. Xiaoxia, Theoretical Questions of International Law [国际法的理论问题] 42 (Tianjin Education Press, 1989).

18 S. Ying, A Biography of Mr. Wang [为王先生写传记], in Selected Works of WANG TiEYA [王铁崖文选] 603 (Zhenglai Deng ed., 2003). 
working at the Ministry of Foreign Affairs continued their research. One research achievement was the PAPER Collection of International LAW ${ }^{19}$ that was later compiled by Professor Chen Tiqiang.

Moreover, InTERnATIONAL LAW ${ }^{20}$ (Volumes 1 \& 2) written by Mr. Zhou Gengsheng was the "first momentous work on international law" ${ }^{21}$ published after 1949. It was "a unique teaching material on international law" before 1981. As a self-contained lawbased work in international law field worldwide, this book filled the research gap between international law in China and global world, and paved the way for the future development.

\section{The Third Phase: Recovery and Development Period (1978-2011)}

It was after the Third Plenary Session of the 11th Central Committee of the Communist Party of China (CCCPC) in 1978 that Chinese international law was fully promoted

\section{a. International law gained growing attention}

First, the government came to realize the importance of international law. For example, in 1996, Chairman Jiang Zemin participated in the legal knowledge lecture held by the CCCPC, at which he stated clearly that: "All comrades that engage in political, economic, cultural and judicial work on behalf of the state should learn knowledge about international law as well." 22 Moreover, academic platforms for international law appeared one after another.

For instance, the Chinese Society of International Law, the first national academic organization in international law in Chinese history, was established in 1980. It was governed by the Ministry of Foreign Affairs, with its first President, Mr. Huan Xiang, a renowned diplomat who had been the Vice President of the Chinese Academy of Social Sciences. In addition, about 80 universities or research centers, including Wuhan University, set up education and research institutes for international law. Finally, academic publications on international law began to increase. ${ }^{23}$ Since the

19 C. Tipiang, A Paper Collection of International Law [国际法论文集] (Law Press, 1985).

20 Z. Gengsheng, International Law [国际法] (Business Press, 1976).

21 C. Tiqiang, A Paper Collection of International Law [国际法论文集] 266 (Law Press, 1985).

22 Jiang Zemin, Speech on International Law at a Lecture on Legal Knowledge Held by the CPC Central Committee [在 中共中央举行的法律知识讲座上关于国际法的讲话], CHINESE Y.B. INT’L L. 1996 [中国国际法年刊 1996] 4 (Law Press, 1997).

23 Zewei Yang, The Features, Problems and Trends of Chinese Science of Public International Law in the Forty Years of Reform and Opening up [改革开放40年来的中国国际公法学: 特点、问题与趋势], 6 WUHAN UnIV. INT'L L. ReV. [武 大国际法评论] 35 (2018). 
Chinese Yearbook of International Law was launched ${ }^{24}$ in 1982, the first academic publication specializing in international law in Chinese history, some international law magazines such as WuHAN University InTERnAtional LAW Review, ${ }^{25}$ Chinese Review of International Law, ${ }^{26}$ and China Oceans Law Review ${ }^{27}$ were launched followed by the first English publication - CHINESE JOURNAL OF INTERNATIONAL LAW. ${ }^{28}$

\section{$b$. The practice of international law was diversified}

Instead of sustaining a negative attitude towards international judicial institutions, first, the Chinese government took the initiative to participate in relevant procedures of international courts and tribunals. In 2009, the Chinese government submitted its opinions in writing on the "Case concerning Advisory Opinion of Unilateral Declaration of Independence in Respect of Kosovo" to the International Court of Justice (ICJ). "This was of great significance, as it was the first time for the People's Republic of China to take part in judicial activity of the International Court of Justice. ${ }^{29}$ In 2010, the Chinese government submitted its written opinions on the "Responsibilities and obligations of States sponsoring persons and entities with respect to activities in the Area (Request for Advisory Opinion submitted to the Seabed Disputes Chamber)" ${ }^{, 30}$ to the International Tribunal for the Law of the Sea (ITLOS). ${ }^{31}$

Second, Chinese scholars actively participated in the practice of international law launched by various international organizations, some of whom could be seen in organizations such as the ICJ, the International Criminal Tribunal for the former Yugoslavia (ICTY), the ITLOS, the United Nations International Law Commission, and the Appellate Body of the WTO. Others even acted as principals of some international organizations. ${ }^{32}$

University)

28 Chinese Journal of InTERnATIONAL LaW [中国国际法论刊].

29 See Selected Cases of Chinese International Law Practice 21 [中国国际法实践案例选编] (PRC Ministry of Foreign Affairs Department of Treaty and Law ed., 2018).

30 Responsibilities and obligations of States sponsoring persons and entities with respect to activities in the Area, Case No. 17, Advisory Opinion of Feb. 1, 2011, ITLOS Rep. 10, https://www.itlos.org/cases/list-of-cases/case-no-17/\#c586.

31 In 2018, the Chinese government submitted a written opinion on the International Court of Justice's advisory opinion on the Legal Consequences of the Separation of the Chagos Archipelago from Mauritius in 1965. See Written Statement of The People's Republic of China, Legal Consequences of the Separation of the Chagos Archipelago from Mauritius in 1965, Advisory Opinion, 2018 I.C.J. Rep. (Mar. 1, 2018).

32 Zewei Yang, The Features, Problems and Trends of Chinese Science of Public International Law in the Forty Years of 
Finally, numerous colleges and universities hosted a number of international law moot court competitions nationwide, such as the Jessup International Law Moot Court Competition, the "International Space Law Moot Court Competition," and so forth.

\section{c. Talents in international law grew rapidly}

In this period, legal education was promoted in China. By the end of 2005, apart from independent colleges and universities and those specializing in law, 559 institutions of higher learning in China had set the law major for undergraduates, with the number of students pursuing bachelor and master's degrees in law reaching $300000 .^{33}$ There was a considerable amount of talents specializing in international law. Moreover, many students had received their master's or doctoral degrees in international law home and abroad. In addition to the three main discipline core courses-Public International Law, Private International Law, and International Economic Law-some institutions of higher education included the following in their teaching plans: Law of International Organizations, International Human Rights Law, Law of the Sea, Law of International Treaties, International Civil Procedure, International Investment Law, International Financial Law, International Trade Law, etc.

\section{Flourishing Period (2012-Present)}

"The kick-off of the 18th National Congress of the Communist Party of China in 2012 marked a new era of the development of the Chinese international jurisprudence." 34 As China has already become the second largest economy in the world, contemporary international law plays a prominent role in safeguarding the national interests of China. Therefore, with the constant reinforcement of organization and guidance on international law research, ${ }^{35}$ consultation agencies

Reform and Opening up [改革开放40年来的中国国际公法学: 特点、问题与趋势], 6 WUHAN UnIV. INT'L L. Rev. [武 大国际法评论] 38 (2018).

33 By the end of 2017, 626 Chinese universities had offered undergraduate majors in law, and more than 310,000 students graduated, majoring in law. See Ministry of Education of the People's Republic of China, http://www.moe.gov.cn/jyb_ xxgk/xxgk_jyta/jyta_gaojiaosi/201611/t20161104_287655.html. See also Lin Zhang \& Lingsheng Zhang, Research and Teaching of International Law in Contemporary China: A Landscape Sketch, 10 J. EAST AsIA \& INT'L L. 429-30 (2017).

34 Zewei Yang, The Features, Problems and Trends of Chinese Science of Public International Law in the Forty Years of Reform and Opening up [改革开放40年来的中国国际公法学: 特点、问题与趋势], 6 WuHAN UnIV. InT'L L. Rev. 39 [武大国际法评论] (2018).

35 For example, the Chinese Society of International Law officially launched its website in 2015, and set up the Award for Outstanding Scientific Research in Chinese and International Law [中国际法学优秀科研成果奖] and the Award for 
specializing in international law were founded. In 2014, the Ministry of Education approved the establishment of the first international law-related "2011 Plan Collaborative Innovation Center of Judicial Civilization": "Collaborative Innovation Center for Territorial Sovereignty and Maritime Rights." In 2015, the Ministry of Foreign Affairs officially approved the founding of the "Expert Advisory Committee for International Law." In this year, Wuhan University Institute of International Law was also approved one of the first plotting entities for the construction of national high-end think tanks by the Publicity Department of the CPC. Finally, more talented individuals joined international law research teams. ${ }^{36}$

Today, China is attaching more importance to the function of international law and increasing efforts to boost its development. In 2014, Wang Yi, the Foreign Minister addressed in a newspaper article, China is a Staunch Defender and Builder of International Rule of Law that: "China, which is committed to rule of law at home, will naturally act as a strong defender and active builder of international rule of law.",37

\section{Main Contributions of PRC to Contemporary International Law}

So far, PRC has made significant contributions to theories and practices of international law through, inter alia, the Five Principles of Peaceful Coexistence and admission and succession, nationality issues, the peaceful settlement of disputes, the "Belt and Road" Initiative, and the building of "a community with a shared future for mankind." "China has taken a constructive part in the formulation of international rules and contributed its input on major issues concerning the interpretation, application and development of international law." ${ }^{38}$ China has concluded 25,000 bilateral treaties, ratified approximately 500 multi-lateral treaties, ${ }^{39}$ and joined almost all intergovernmental organizations.

Emerging International Law [国际法新锐奖].

36 Ming Li, Report on the Work of the Council of the China Society of International Law (2013-18) [中国国际法学会理 事会工作报告(2013-18)] (May 19, 2018).

37 Wang Yi, China is a Staunch Defender and Builder of International Rule of Law [中国是国际法治的坚定维护者和建 设者], GuAngming DaILY [光明日报], Oct. 24, 2014.

38 Id.

39 Selected Cases of Chinese International Law Practice, supra note 29, at 81. 


\section{A. Five Principles of Peaceful Coexistence}

The Five Principles of Peaceful Coexistence address the mutual respect for sovereignty and territorial integrity, mutual non-aggression, non-interference in each other's internal affairs, equality and mutual benefit, and peaceful coexistence. These are a set of systematic international law principles and systems jointly proposed by China, India, and Myanmar in the 1950s. After its proposal, the Five Principles of Peaceful Coexistence were supported by many countries and prescribed in numerous international legal documents as a basic maxim guiding contemporary international law and relations. ${ }^{40}$

The Five Principles of Peaceful Coexistence are taking national sovereignty as its core concept and principle. The Five Principles highlight "Law of Reciprocity" for building and guaranteeing just and reasonable international orders. ${ }^{41}$ President Xi Jinping addressed: "In the new era today, the spirit of the Five Principles of Peaceful Coexistence, instead of being outdated, remains as relevant as ever; ... its significance, rather than diminishing, remains as important as ever; and its role, rather than being weakened, has continued to grow."42

\section{B. Recognition in International Law}

Since its establishment in 1949, PRC has shaped its consistent stance and attitude toward the question of recognition.

\section{Government Recognition}

PRC was established by overturning the previous nationalist government. ${ }^{43}$ Therefore, it needed to be recognized as a sole legitimate government in mainland China. In this regard, PRC has made the following two contributions.

One is the Recognition with "Adverse Requirements." At that time, the PRC government required foreign countries to recognize it as the sole legitimate

40 Hanqin Xue, Chinese Contemporary Perspective on International Law: History, Culture and International Law, 355 ReCueIL DEs Cours [Collected Courses of The Hague Academy of International Law] 68 (2011).

41 Zewei Yang, An Analysis of the Relationship Between International Order and State Sovereignty [国际秩序与国家主 权关系探析], 6 LEGAL SCI. [法律科学] 84, (2004).

42 See Xi Jinping's Speech at The Five Principles of Peaceful Coexistence of 60th Anniversary Conference [习近 平在和平共处五项原则发表60周年纪念大会上的讲话], XINHUANET, June 28, 2014, http:/www.xinhuanet.com/ politics/2014-06/28/c_1111364206.htm.

43 Xue, supra note 40 , at 65.

44 Tiqiang Chen, Recognition about The People's Republic of China [中华人民共和国与承认问题], ChINESE Y.B. INT'L L. [中国国际法年刊] 24 (1985). 
government representing all China. It means that no country was allowed to maintain diplomatic relations with the so-called "government of the Republic of China" in Taiwan, while recognizing the government of the People's Republic of China. ${ }^{45}$ Thus, any country with the diplomatic relationship with PRC should uphold the "One China" policy in its State practice towards recognition. ${ }^{46}$

The other is that recognition was 'reciprocal.' This was quite true when it came to the recognition between PRC and Canada, Austria, Mali, and the US. Both parties merely showed the intent to establish diplomatic relations without a formal expression of "recognition." 47

\section{Recognition of State and Government by PRC}

When a country regained the sovereignty from colonial rule, PRC recognized its statehood under the right of national self-determination. In 1958, for instance, the PRC government recognized the Algerian provisional government set up in Cairo, Egypt as the sole legitimate government of the Algerian people. ${ }^{48}$ Meanwhile, the PRC government adhered to the principle of non-interference in the internal affairs of other countries. It would not impose its own ideology on other countries. For example, when the new governments emerged in Eastern Europe after the dissolution of the Soviet Union in 1989, PRC promptly recognized them as legitimate governments. $^{49}$

\section{Succession in International Law}

\section{Treaty Succession}

Article 55 of the Common Program of the Chinese People's Political Consultative Conference in 1949 provides: "The Central People's Government of the People's Republic of China shall examine the treaties and agreements concluded between the Kuomintang and foreign governments, and shall recognize, abrogate, revise, or re-negotiate them according to their respective contents. ${ }^{, 50}$ This provision defined

\footnotetext{
45 Compilation of Documents on the Foreign Affairs of the People’s Republic of China (1949-50) [中华人民共和国对 外关系文件集 (1949-50)] (1957).

46 Xue, supra note 40 , at 70-4.

47 Chen, supra note 44 , at 27.

48 Qianyu Li, On China-Algeria Relations During Algeria's Struggle for National Independence (1958-1962) [试论阿尔 及利亚争取民族独立斗争期间的中阿关系 (1958-1962)], 2 COLD WAR INT'L HIST. STUD. [冷战国际史研究] 93 (2012).

49 Huhua Wang (ed.), Public International Law [国际公法学] 104 (2015).

50 The Common Program of Chinese People's Political Consultative Conference, Sept. 29, 1949, art. 54, https:// sourcebooks.fordham.edu/mod/1949-ccp-program.asp.
} 
the general principle of the PRC government on the succession of treaties. Among the treaties concluded by the nationalist government, some were recognized, some remained valid after revisions, while others were abrogated by the PRC government.

\section{Property Succession}

Under international law, PRC was entitled to succeed all the properties legitimately within and beyond the territory of China that the nationalist government owned prior to its establishment. Regarding the ownership of overseas property in Hong Kong, Singapore, and other regions, it solemnly stated that all national property of China naturally belonged to the PRC. ${ }^{51}$ The PRC government showcased its stance on the succession of property in the practice of the Khoka-Ryo Student Dormitory Case." $^{, 52}$

\section{Debts Succession}

The PRC government treated debts differently following the nature and conditions of debts. No "odious debts" were recognized, while legitimate debts were negotiated with related countries justly and reasonably. For instance, after the Huguang Railway Bonds Case in the US, the so-called "Case of Unsolved Old Bonds of Morris" that took place in the US in 2005 was another case of unsolved old bonds involving the Chinese government, whose settlement fully displayed the basic stance of the PRC government regarding the succession of debts. ${ }^{53}$

\section{Peaceful Settlement of Disputes}

\section{Negotiation and Consultation}

PRC always settle international disputes peacefully through negotiation and consultation, ${ }^{54}$ including boundary issues involving China. ${ }^{55}$ Currently, China has signed boundary treaties with 12 adjacent countries, ${ }^{56}$ which resolved the boundary issues with these countries fully or essentially. Likewise, China and Vietnam officially signed the Agreement between the People's Republic of China

51 Gengsheng Zhou, International Law [国际法] 160 (Business Press, 1981).

52 Kitamura Tomofumi, Japanese Supreme Court Judgement in the so-called “Khoka-ryo Case," 7:3 CHINESE J. INT'L L. 713-20 (2008). See also Nisuke Ando, The Khoka-Ryo Case and International Law: A Critique of the Japanese Supreme Court Decision, 53 JAPANESE Y.B. INT'L L. 1-8 (2010).

53 Jielong Duan, International Law in China: Cases and Practice [中国国际法实践与案例] 38-43 (Law Press, 2011).

54 ZHоU, supra note 51, at 759.

55 DuAn, supra note 53, at 165.

56 Xue, supra note 40 , at 85. 
and the Socialist Republic of Vietnam on the Delimitation of the Territorial Seas, the Exclusive Economic Zones and Continental Shelves in Beibu Bay/Bac Bo Gulf in $2000 .^{57}$ PRC also resolved the territory issues with the UK and Portugal successfully through the Joint Declaration of the Government of the United Kingdom of Great Britain and Northern Ireland and the Government of the People's Republic of China on the Question of Hong Kong and the Sino-British Joint Declaration on the Question of Hong Kong, Joint Declaration of the Government of the People's Republic of China and the Government of the Portuguese Republic on the Question of Macao. ${ }^{58}$ These Declarations were highly reputed in the international society. ${ }^{59}$

\section{International Arbitration}

PRC has been reluctant to international arbitration. Excepting some foreign trade protocols stipulating certain arbitration methods, ${ }^{60}$ there is no single arbitration provision included in any general international treaty. When joining multi-lateral treaties or international conventions, China has held a reserved attitude towards arbitration as a solution for disputes. In practice of resolving territory conflicts with adjacent counties, for example, the PRC government prefers negotiation and consultation to arbitration.

In 2013, when the Philippines requested a compulsory arbitration concerning South China Sea disputes with China in accordance with Article 287 of the United Nations Convention on the Law of the Sea and Appendix VII thereto, ${ }^{61}$ the PRC government solemnly stated that it would neither accept, nor take part in any arbitration applied by the Philippines. ${ }^{62}$ Nevertheless, China has recently adjusted its policies towards arbitration in case of non-political international treaties, namely, those of economy, trade, technology, and culture. In this regards, China began to include arbitration provisions therein as a method of international disputes settlements. Today, China would apply arbitration for dispute settlement in economy, trade, and maritime transportation. ${ }^{63}$

\footnotetext{
57 This is the first maritime boundary China has demarcated with its neighbors in accordance with the United Nations Convention on the Law of the Sea 1982.

58 Xue, supra note 40 , at 82.

59 Jiuyong Shi, Autonomy of the Hong Kong Special Administrative Region, 11 LeIDEN J. InT'L L. 63-70 (1998).

60 See A Collection of the Treaties of the People’s Republic of China (1949-60) [中华人民共和国条约集(1949-60)] 91-138 (PRC Ministry of Foreign Affairs Department of Treaty and Law ed., 1958).

61 Zewei Yang, On the Ineffectiveness of the Arbitration Between China and the Philippines in the South China Sea [论中 菲南海仲裁案裁决的无效性], 6 CONTEMP. WORLD [当代世界] 14-5 (2016).

62 PRC, Position Paper on the Matter of Jurisdiction in the South China Sea Arbitration Initiated by the Republic of the Philippines (Dec. 7, 2014), https://www.fmprc.gov.cn/nanhai/eng/snhwtlcwj_1/t1368895.htm.

63 DuAn, supra note 53, at 371.
} 


\section{International Court and Tribunal}

\section{a. International Court of Justice}

For nearly two decades after the establishment of PRC, relations between the Chinese government and the ICJ were merely a blank sheet. ${ }^{64}$ In 1972, the Chinese government declared: "It would not recognize the Statement on Acceptance of Compulsory Jurisdiction by the International Court of Justice made by the previous government on October 26, 1946. ${ }^{, 65}$ Actually, PRC had never concluded any special agreement with any country on submitting international disputes to the ICJ. China reserved nearly all terms and conditions of international conventions on the submission of disputes to the ICJ for settlement. Until today, China has never submitted any international conflict or case to the ICJ. ${ }^{66}$

\section{b. International Tribunal for the Law of the Sea}

The PRC government ratified the United Nations Convention on the Law of the Sea (UNCLOS) in 1996 and Zhao Lihai, Xu Guangjian, Gao Zhiguo and Duan Jielong from China have held the position of judges of the ITLOS. In 2006, according to Article 298 of the UNCLOS, it submitted a statement to the UN Secretary-General:

In regard to any dispute (i.e. disputes related to division of sea, territory and military actions) set forth in Item (a), (b) and (c) of Clause 1 of Article 298 in the United Nations Convention on the Law of the Sea, the government of the People's Republic of China would not subject itself to any international judicial or arbitral jurisdiction provided in Section II of Part XV of the United Nations Convention on the Law of the Sea. ${ }^{67}$

Regarding disputes involving the division of sea, historical gulfs or their ownership, military and enforcement activities, and the Security Council's performance of duties empowered by the UN Charter, the PRC government would thus accept neither any settlement procedure of disputes under of Part XV, Section II of the UNCLOS, nor the jurisdiction of the ITLOS. Until today, China has not submitted any international conflict or case to the ITLOS.

64 After the founding of the PRC, from 1949 to 1971, its lawful seat in the UN was occupied by the Taiwanese authorities. This is based on the fact that the Chinese were on both sides of the partition at this stage. The PRC was excluded from the UN and could not have any contact with the ICJ, while Taiwan's authorities remained in contact with the ICJ. After Xu Mo's death in 1956, Gu Weijun succeeded him as a judge member of the Court, until 1967. See Zewei Yang, Liang Zhu's InTERnATIONAL OrganiZATION LAW [梁著国际组织法(第六版)] 104 (Wuhan University Press 6th ed., 2011).

65 Jielong Duan, International Law in China: Cases and Practice [中国国际法实践与案例] 368-9 (Law Press, 2011).

66 Xue, supra note 40, at 193.

67 United Nations Convention on the Law of the Sea, Dec. 10, 1982, 1833 U.N.T.S. 397. 


\section{E. The "Belt and Road" Initiative}

The "Belt and Road" Initiative, which was proposed by Chairman Xi Jinping in 2013, gained significant attention from the international society and active responses from the relevant countries. The National Development and Reform Commission, the Ministry of Foreign Affairs, and the Ministry of Commerce jointly published the Vision and Actions on Jointly Building Silk Road Economic Belt and 21st-Century Maritime Silk Road in 2015. ${ }^{68}$ The next year, 193 member states of the United Nations unanimously approved a resolution to build the "Belt and Road" and to be bound by related initiatives for economic cooperation, as well as to urge the international society to create a safe environment that would serve as a guarantee for the building of the "Belt and Road." 69 In the Security Council Resolution 2344 (the situation in Afghanistan), the "Belt and Road" Initiative was referred to for the first time. ${ }^{70}$ By the end of March 2020, China signed 200 intergovernmental documents with 138 countries and 30 international organizations on joint efforts to build the "Belt and Road." "Working together to build the "Belt and Road" is, so to speak, becoming a Chinese scheme in its participation of global opening-up and cooperation, improvement of global economic and political systems, promotion of global development and prosperity and acceleration of building a Community of Shared Future for Mankind.,"72

As a new mode in international partnership, new platform for global governance, and new dimension for international cooperation in different regions under international law, the "Belt and Road" Initiative has influence on the development of contemporary international law in multiple arenas, such as boosting the advancement of the basic principles of international law, optimizing the international system of transit transport, and enriching the implementation of international law and of international systems on development assistance. The "Belt and Road" Initiative complies with the new trends for the 21st century's international cooperation and

68 National Development and Reform Commission (Ministry of Foreign Affairs and Ministry of Commerce of the PRC), Vision and Actions on Jointly Building Silk Road Economic Belt and 21st-Century Maritime Silk Road (Mar. 28, 2015), https://www.fmprc.gov.cn/mfa_eng/zxxx_662805/t1249618.shtml.

69 U.N. Doc. G.A. Res. 71/9 (Nov. 17, 2016), https://undocs.org/en/A/RES/71/9.

70 U.N. Doc. S.C. Res. 2344 (Mar. 17, 2017), https://undocs.org/en/S/RES/2344(2017).

71 The Joint Initiative of “One Belt And One Road”: Progress, Contribution and Prospect [共建 “一带一路” 倡议: 进 展、贡献与展望], https://www.yidaiyilu.gov.cn/zchj/qwfb/86697.htm.

72 See Xi Jinping's Speech at the Symposium Marking the 5th Anniversary of the Construction of One Belt and One Road [习近平在推进 “一带一路” 建设工作5周年座谈会上的讲话] (Feb. 5, 2019), http://www.yidaiyilu.gov.cn/xwzX/ xgcdt/79168.htm. 
embodies a new and revolutionary world orders. ${ }^{73}$

\section{F. A Community of Shared Future for Mankind}

To build “a Community of Shared Future for Mankind [人类命运共同体] is an important component of Xi Jinping's Thoughts on Socialism with Chinese Characteristics for a new era. It is also a general target, overall outline, and strategy for Chinese diplomacy in the new era. ${ }^{74}$ In 2017, Chairman Xi Jinping gave a keynote speech titled, Work Together to Build a Community of Shared Future for Mankind at the UN headquarters in Geneva, proposing the principles for building a Community of Shared Future for Mankind and the orientation of such efforts. ${ }^{75}$

In 2018, "promoting the building of a Community of Shared Future for Mankind" was included in the PRC Constitution. ${ }^{76}$ It contains five pillars, namely, "lasting peace, universal security, common prosperity, openness and inclusiveness, cleanness and beauty," making it rich in connotations found in international law. "The thought of promoting the building of a Community of Shared Future for Mankind is a core concept of Chinese view on international law in the new era and a major theoretical contribution by China to the development of international law."

On the one hand, the concept of "a Community of Shared Future for Mankind" has indicated the advanced pursuit of value, which is beneficial to the revolution of international law in this profoundly changing global society. The concept of "a Community of Shared Future for Mankind" comprises such notions as international law, namely, sovereignty, democracy, fairness, and justice. It involves all aspects of human life and embodies the development trend of international relations towards democracy and legality. ${ }^{79}$ On the other hand, "a concept of a Community of Shared Future for Mankind" is a positive outcome of the Five Principles of Peaceful Coexistence. To a certain extent, the principles of "a Community of Shared Future for Mankind" are upgraded version of the previous Five Principles proposed six

73 Zewei Yang, Understanding the Belt and Road Initiative under Contemporary International Law, 5 CHINA \& WTO ReV. 316-8 (2019).

74 Hong Xu, Community with Shared Future for Mankind and International Law [人类命运共同体与国际法], 5 CHINESE REV. INT'L L. [国际法研究] 3-14 (2018).

75 Xi JinPING: The Governance OF ChinA [习近平谈治国理政] 546-7 (Foreign Languages Press, 2017).

76 P.R.C. Const. (2018) pmbl., https://npcobserver.files.wordpress.com/2018/12/PRC-Constitution-2018.pdf.

$77 \mathrm{Xu}$, supra note 74 , at 6.

78 Selected Cases of Chinese International Law Practice, supra note 29, at 20.

79 Research Team on Community of Shared Future for Mankind and International Law, Building a Community of Shared Future for Mankind via International Law [人类命运共同体的国际法构建], 1 WuHAN UNIV. INT'L L. Rev. [武大国际 法评论] 9 (2019). 
decades ago representing the cutting edge of the new era. ${ }^{80}$

\section{Main Characteristics and Problems of Chinese International Law}

\section{A. Main Characteristics of Chinese International Jurisprudence for the past 70 Years}

1. Paying attention to the principles of international law of topical issues.

For the past 70 years, Chinese international law scholars have commented the major issues of international relations such as the Korean War (1950-53), ${ }^{81}$ the Iran hostage crisis (1979), ${ }^{82}$ the signing of the UNCLOS (1982), ${ }^{83}$ the Gulf War (1991), ${ }^{84}$ the establishment of the World Trade Organization (1995), ${ }^{85}$ the Pinochet Case (1998), ${ }^{86}$ the "September 11 Attacks" and War on Terror (2001) (2003), ${ }^{87}$ the Iraq War (2003), ${ }^{88}$ the Beijing Olympic Games (2008), ${ }^{89}$ Crimea's vote to join Russia (2014), ${ }^{90}$ the Paris Agreement on Climate Change (2015), ${ }^{91}$ and the South China Sea arbitration case (2016). ${ }^{92}$

$80 \mathrm{Xu}$, supra note 74 , at 9.

81 Haopei Li, On the Illegality of US Intervention in China and North Korea [论美国干涉中国及朝鲜的非法], in SElEctions From Li HAOPEI [李浩培文选] 533-7 (Law Press, 2000).

82 Lihai Zhao, The Iran-US Affair and International Law - Extradition, Hostages, Diplomatic Immunity [伊美事件与国际 法-引渡、人质、外交豁免权], 1 LEGAL SCI. MAG. [法学杂志] 1-5 (1980).

83 Lihai Zhao, New developments in the Law of the Sea [海洋法的新发展] (Peking Univ. Press, 1984).

84 Lijun Yang, The United Nations Collective Security System from the Gulf War [从海湾战争看联合国集体安全制度], CHINESE Y.B. INT’L L. [中国国际法年刊] 311-27 (1992).

85 Lingliang Zeng, The WTO Law [世界贸易组织法] (Wuhan Univ. Press, 1996).

86 Zhonghai Zhou (ED.), Analysis of the Pinochet Case [皮诺切特案析] (CUPL Press, 1999).

87 Liang Xi, Rational Reflection after “9.11c Affair [国际法律秩序的呼唤-“9-11”事件后的理性反思], 1 L. REV. [法学 评论] 3-11 (2002).

88 ShapIng SHAo ET AL. (EDS.), The Impact of Iraq War on International Rule of Law [伊拉克战争对国际法治的冲击和影 响], 3 LEGAL F. [法学论坛] 5-10 (2003).

89 Shixi Huang, Olympic Legal Issues [奥运会法律问题] (Law Press, 2008).

90 Lingliang Zeng, International Law Issues Related to Crimea's "Decession from Ukraine and Annexation from Russia" [与克里米亚 “脱乌入俄事件” 有关的国际法问题], 1 CHINESE REV. INT’L L. [国际法研究] 3-13 (2015).

91 Wei Gong \& Hui Zhao, Analysis of US Withdraws from Paris Agreement from the Perspective of International Law [国退出〈巴黎协定〉的国际法分析], 2 J. GuIZHOU U. [贵州大学学报(社会科学版)] 109-15 (2018).

92 Chinese Society of International Law, Special Issue on Jurisdiction of the South China Sea Arbitration [中国国际法年 刊: 南海仲裁案管辖权问题专刊], CHINESE Y.B. INT’L L. [中国国际法年刊] 1-424 (2016). 
In addition, some scholars have studied theories and practice of $\mathrm{WTO},{ }^{93}$ the United Nations reform, ${ }^{94}$ the International Criminal Court, ${ }^{95}$ and so forth, all of which are of distinct characteristics of the contemporary world. This close combination has served as important legal grounds for the relevant policies made by the Chinese government.

\section{Attaching Importance to the Combination of Chinese Practice}

For instance, Chinese scholars have made suggestions on the history of Chinese international law, ${ }^{96}$ the boundary issue between China and India, ${ }^{97}$ Chinese Nationality Law, $^{98}$ the Huguang Railway Bonds Case, ${ }^{99}$ America's sale of weapons to Taiwan, ${ }^{100}$ treaty law ${ }^{101}$ Khoka-Ryo Student Dormitory Case, ${ }^{102}$ the Yinhe (Milky Way) incident, ${ }^{103}$ the China-US Aircraft Collision Incident/Hainan Island incident, ${ }^{104}$ the Sino-Japanese Dispute on Sovereignty over the Diaoyu/Senkaku Islands, ${ }^{105}$ the Joint Development in the South China Sea, ${ }^{106}$ and the G20 Hangzhou Summit. ${ }^{107}$

93 Wanzhong Sun, Research on WTO Theory and Practice [WTO理论和实践研究] (Zhejiang Univ. Press, 2007).

94 Shibin Yuan, UN Mechanism and Reform [联合国机制与改革] (Beijing Languages College Press, 1995).

95 YanPing Gao, International CRiminal Court [国际刑事法院] (World Affairs Press, 1999).

96 Tieya Wang, China's First International Law Academic Group [公法学会-中国第一个国际法学术团体], CHINESE Y.B. InT’L L. [中国国际法年刊] 372-6 (1996); Zewei YANG, ON THE History of InTERNATIONAL LAW [国际法史论] (Higher Education Press, 2011).

97 Gengsheng Zhou, International Law Does Not Support India's Position on the China-India Boundary Issue [国际法并 不支持印度对中印边界问题的立场], PeoPLE'S DAILy [人民日报], July 26, 1961.

98 Haopei Li, Comparative Study of Nationality Issues [国籍问题比较研究] (Law Press, 1979).

99 Tiqiang Chen, State Sovereign Immunity from International Law - on Huguang Railway Bonds Case [国家主权豁免于 国际法-评湖广铁路债券案], CHINESE Y.B. INT’L L. [中国国际法年刊] 31-53 (1983).

100 Tiqiang Chen, American's Sale of Weapons to Taiwan from the Perspective of International Law [从国际法论美国向 台湾出售武器问题], People’s DaILy [人民日报], Feb. 5, 1982.

101 Tieya Wang, The Status of Treaties in China's Legal System [条约在中国法律制度中的地位], CHINESE Y.B. INT'L L. [中国国际法年刊] 3-18 (1994).

102 Houli Wang \& Hanqing Xue, The Khoka-Ryo Student Dormitory Case from the Perspective of International Law [光华 寮案的国际法问题研究], CHINESE Y.B. INT’L L. [中国国际法年刊] 223-41 (1988).

103 Shao Jin, International law in the Yinhe Incident [“银河号” 事件的国际法问题], 6 PeKING UNIV. L. J. [中外法学] 9-13 (1993).

104 Wenzong Liu, Comment on the U.S. Government's Evasion of China-US Aircraft Collision Incident [欲盖弥彰, 难辞 其各-评美国政府对海南撞机事件的遁词], 2 FoREIGN AFF. REv. [外交学院学报] 24-6 (2001).

105 Guoqiang Luo, The Way to Resolve the Diaoyu Islands Dispute [钓鱼岛争端的解决进路辨析], 12 PAC. J. [太平洋学报] 90-6 (2012).

106 Zewei Yang, Research on the Legal Basis, Development Trend and Realization Path of Maritime Joint Development in China [论海上共同开发的法律依据、发展趋势及中国的实现路径], CHINESE Y.B. INT’L L. [中国国际法年刊] 110-39 (2015).

107 Guohua Yang, G20 Hangzhou Summit and WTO Development [G20杭州峰会与WTO的发展], CHINESE Y.B. INT'L L. [中国国际法年刊] 325-47 (2016). 


\section{Enlarging Fields of International Law by Chinese Lawyers}

After World War II, the European and American lawyers developed teaching materials mainly focusing on the law of peace, while "the law of war was either neglected or introduced with simple words." ${ }^{108}$ In particular, the scope of international law has been fast expanding due to the scientific development. ${ }^{109}$ In this course, Chinese international lawyers have been exploring new research areas such as outer space law recently valued in China. ${ }^{110}$ They have deep interest in the law of international organizations, ${ }^{111}$ international human rights law, ${ }^{112}$ international criminal law, ${ }^{113}$ and migrant and refugee law. ${ }^{114}$ Furthermore, Professor Yang Zewei and his research team conducted significant research on international energy law. ${ }^{115}$ They systematically demonstrated that international energy law was a breakthrough for the development of international law. ${ }^{116}$ The research achievements of Chinese international lawyers over the past 70 years have not been even, with those in the latter 35 years far exceeding the former.

\section{B. Major Problems in Chinese International Law}

1. The Lack of Systematic Approaches to the Theories and Practice of International Law International law in China has developed in many different dimensions. Hence, it is necessary for Chinese international lawyers to make systematic summaries and descriptions on the theories and practices of international law for the last 70 years in order to elaborate on the stance and interests of the PRC on international law and its significant contributions to the development of contemporary international law. Summarizing the theories and practices of international law is significant to not only China's foreign policymaking, but also Chinese research of international law. ${ }^{117}$

\footnotetext{
108 Tiqiang Chen, A Collection of International Law [国际法论文集] 267 (Law Press, 1985).

109 M. Shaw, International Law 300 (8th ed. 2017).

110 Qizhi He, Law of Outer Space [外层空间法] (Law Press, 1992); Han Wang (ed.), Monograph on International Air LAW [国际航空法专论] (Law Press, 2017).

111 Zewei Yang, Liang Zhu's International Organization Law [梁著国际组织法(第六版)] (6th ed. 2011); Geping RaO (ed.), The Law of International Organizations [国际组织法] (Peking Univ. Press, 1996).

112 Shiyan Sun, Obligations of States Parties of International Covenant on Civil and Political Rights [<公民及政治 权利国际公约>缔约国的义务] (Social Sciences Academic Press, 2012).

113 Shaping Shao, Modern International Criminal Law [现代国际刑法教程] (Wuhan Univ. Press, 1993).

114 Guofu Liu, International Refugee Law [国际难民法] (World Affairs Press, 2014).

115 Zewei Yang, New Energy Law and Policy Studies Series [新能源法律政策研究从书] (Wuhan Univ. Press, 2011).

116 Zewei Yang, Research on Legal Protection of EnERgy Security in China [中国能源安全法律保障研究] (CUPL Press, 2009).

117 Jielong Duan (ed.), International Law in China: Cases and Practice [中国国际法实践与案例] (Law Press, 2011)
} 


\section{Participation in International Legislation and International Judicial Activities}

It was not until 1971 that PRC recovered its legitimate seat in the UN. Then, the PRC government sent a delegation to attend the Third United Nations Conference on the Law of the Sea; recommended the candidates for the members of the UN International Law Commission, judges of the ICJ, the ITLOS, the ICTY, and the Dispute Settlement Body of the World Trade Organization, as well as principals of some intergovernmental international organizations. Nevertheless, PRC has not represented its positions enough in international legislation and international judicial activities. Regarding the agenda-setting and drafting of international treaties, for example, China has generally adopted the so-called "e-post game" strategy, which means developed countries take the initiative to propose subjects to be discussed and drafts for international treaties, whereas China, as a participant, ${ }^{118}$ responds to them in a passive manner. ${ }^{119}$ Typical examples are lawmaking process of the WTO and climate change. China also maintains a negative attitude towards dispute settlement through international court or tribunal. It has never submitted a single conflict to the ICJ or ITLOS. Worse still, Chinese judges are not so positive in the decision-makings of international courts and tribunals.

\section{Lack of Theories Supporting the Foreign Policymaking or Practice.}

Basic theory of international law has remained a vulnerable link in Chinese international law research. When it comes to some fundamental issues related to international law theory, no comprehensive, systematic, or in-depth studies are found. In particular, Chinese research on international law, mainly focusing on the traditional theories and certain cases, fails to fully integrate with the overall development strategy or foreign policymaking as a whole. Chinese international law circles have not yet provided influential ideas, concept and suggestions with global impact.

Conversely, the US has proposed the "preventive self-defense" theory ${ }^{120}$ in the early 21st century along with the War on Terror and the "International Commission on Intervention and State Sovereignty" in Canada has proposed the "Responsibility to Protect (R2P)" theory. ${ }^{121}$ Though we may not fully agree with these theories,

118 Yien Jiang, An Overview of American Scholars' Research on the Relationship between China and International Organizations [美国学者关于中国与国际组织关系研究概述], 8 WORLD ECON. \& Politics [世界经济与政治] 48-53 (2001).

119 Lingliang Zeng, China's Practice of International Rule of Law for 30 Years: Achievements and Challenges [中国践行 国际法治30年: 成就与挑战], 1 WuHAN UnIV. InT'L L. Rev. [武大国际法评论] 18 (2011).

120 Zewei Yang, International Law [国际法(第三版)] 74-5 (China Higher Education Press, 3d ed., 2017).

121 Zewei Yang, The “Responsibility to Protect” and its Implications for National Sovereignty [“保护的责任” 及其对国 
the abovementioned theories have undoubtedly wielded great influenced in the international society. Some scholars noted:

In contrast to traditional strong powers in international law, the awareness, experience, capacity and mechanism of full utilization of international law is not developed in China. Instead, their development is unbalanced and it is obvious that China is weak in participation into and employment of international judicial institutions. $^{122}$

\section{Rare International Law Scholarship with Global Influence}

Over the past 70 years, many academic works of international law have been published in PRC. These articles and books have been playing a significant role in cultivating talents in international law in China, sharing international law with people all over the country, and maintaining national interests. With the exception of works by leading scholars like Chen Tiqiang and Wang Tieya, however, very few have global influence. Indeed, China is not the hometown of modern international law and Chinese is not generally spoken among international lawyers for their research and practice. These are critical factors restricting the academic impact of the works written by Chinese international law scholars. Still, to launch great academic works with global impact like OpPenheim's InTERnational LaW, PRINCIPLES OF PUblic INTERNATIONAL LAW (I. Brownlie), INTRODUCTION TO INTERNATIONAL LAW (J. Stark), and InTERnATIONAL LAW (M. Show) ${ }^{123}$ is a lofty dream that Chinese international law scholars should follow.

\section{Conclusion and Prospects: Future Direction of Chinese International Law Studies}

\section{A. Interpretation and Application of International Law}

As international law is dominated by treaties and customs, its interpretation and application would easily encounter contradictions and divergences. However, there are new trends along the development of international law such as: fierce conflicts between the fragmentation of international law and its unified application,

家主权的影响], 5 LuOJA LeGAL F. [珞珈法学论坛] 40-8 (2006).

122 Selected Cases of Chinese International Law Practice, supra note 29, at 20.

123 SHAw, supra note 109, at 1-253. 
powerful expansion of treaties concerning human rights protection, the execution of adjudications of the international court and tribunal like ITLOS, as well as more independent opinions of the ICJ judges. These factors are representing the immense division of power and growing diversity of interests in today's international society. In order to provide a legal basis for these changes and protect their own interests, each country offers lopsided explanations of international law that are favorable only to them. Because the South China Sea arbitration was unilaterally applied by the Philippines alone in 2013, the relevant terms and conditions in the UNCLOS were misinterpreted by the Philippines and the arbitration court. Therefore, it is necessary for Chinese international lawyers to consider and apply international law for better justice and rule of law in the global community.

\section{B. Further Improvement of Theoretical Innovation in International Law}

Recent years have witnessed significant changes in international relations. On the one hand, while the US hegemony is decreasing, comprehensive national strength of the emerging powers continue to grow. On the other hand, China has become not only the second largest economy in the world, but also political hegemony. Against such backdrop, China should invoke international law for its overall development strategy supporting diplomatic practice. To this end, Chinese international law scholars should boost theoretical innovation in international law. Thus, the Chinese international law society should propose, in a timely fashion, new ideas or outlooks of international law that address Chinese national position for international peace and prosperity which can be recognized by the international community. Those universal approaches to international law will lead core value of the world.

\section{Amplifying China's Voice in the Development of International Law}

In the past, China played a limited role in international law-making. As a "latecomer" and "reformer" of the international law system, it lagged behind in terms of agendasetting, developing voice, and formulating regulations for the development of international law. Because a pattern of "strong in the west but weak in the east" and intensive "western color" and "European style" still remains, China's voice is too weak in international law research and practice. Since 2012, however, China has been no longer satisfied with mere participation in international legislation process. Instead, it is trying to shape and affect international laws and global governance. 
Chairman Xi Jinping expressed in his speech upon the invitation of the Korber Foundation in Berlin, Germany in March 2014: "With the lofty cause of peace and development of the world in mind, we will contribute the Chinese vision to the management of contemporary international relations, offer the Chinese solution for improving global governance, and work with the international society to meet various challenges of the 21st century.",124

Hence, to reinforce China's voice and ground in the development of international law, it will "improve and value international law, utilize international law and shape the awareness of international law in an all-rounded manner, be more active and positive in proposing Chinese schemes and propositions with clear stands for the development of international law and strive to realize the fundamental transformation of China from the receiver and participant into constructer, contributor and leader in international orders, rules and concepts, ${ }^{, 125}$ and meet the aspirations of international society. These are the important missions that have been bestowed upon Chinese international lawyers in the next decades. 